\title{
COMMENTARY
}

\section{Etomidate for intubation of patients who have sepsis or septic shock - where do we go from here?}

\author{
Donald EG Griesdale1,2,3 \\ See related research by Jung et al., http://ccforum.com/content/16/6/R224
}

\begin{abstract}
Etomidate is an intravenous induction agent that is associated with hemodynamic stability during intubation. The agent is therefore attractive for use in critically ill patients who have a high risk of hemodynamic instability during this procedure. However, etomidate causes adrenal suppression, which itself has been associated with increased mortality in critically ill patients. The ongoing debate surrounding use of etomidate is thus centered on the immediate favorable hemodynamic profile versus the long-term risks of adrenal insufficiency, particularly in patients who have severe sepsis or septic shock.
\end{abstract}

In this issue of Critical Care, Jung and colleagues reported on their single-center observational cohort study that compared etomidate with other induction agents to facilitate intubation in the 48 hours before the onset of shock in patients who had septic shock [1]. Based on local practice, all of these patients received hydrocortisone supplementation after a corticotropin stimulation test. This practice provided a unique opportunity to examine an important gap in the current literature: the risks and benefits of etomidate in septic shock in the context of universal hydrocortisone supplementation. Importantly, this study confirmed that immediate life-threatening complications, including severe hypotension, are common (37 of 102 patients) during the intubation period. Patients who received etomidate were

*Correspondence: donald.griesdale@vch.ca

'Department of Medicine, Division of Critical Care Medicine, Vancouver General Hospital, University of British Columbia, 855 West 12th Avenue, Vancouver, BC, Canada V5Z $1 \mathrm{M} 9$

Full list of author information is available at the end of the article more severely ill at baseline, which may explain why their physicians chose to use this agent. Consistent with other published results [2-4], patients who received etomidate had lower serum cortisol concentrations after intubation and a higher percentage of nonresponse to the corticotropin stimulation test compared with patients who received another induction agent (79\% vs. 52\%, $P=0.01)$. Patients who received etomidate also required a longer duration of hydrocortisone supplementation and a higher cumulative dose of norepinephrine compared with the non-etomidate group. Multivariable Cox regression demonstrated a decreased mortality rate in patients who had received etomidate (hazard ratio $=0.33$, $95 \%$ confidence interval $=012$ to $0.90, P=0.03$ ) after adjusting for severity of illness. It is important to note that the mortality signal favoring etomidate was contrary to the authors' a priori hypothesis.

The current study adds considerably to the limited evidence concerning use of etomidate in patients who have severe sepsis or septic shock. A post-hoc analysis of the Corticosteroid Therapy of Septic Shock (CORTICUS) trial showed that patients who received etomidate were more likely not to respond to corticotropin and had an increased mortality rate at 28 days ( $43 \%$ vs. $31 \%, P=0.03$ ) compared with patients who did not receive etomidate [2]. Use of hydrocortisone did not appear to substantively modify this relationship [5]. In CORTICUS, the median time between receiving etomidate and randomization to steroids (or not) was 14.5 hours (interquartile range = 4.25 to 28.4 hours) [5]. In contrast, the patients in the current study received hydrocortisone within 9 hours (interquartile range 5 to 19 hours) of intubation. Time may therefore be an important effect modifier in this analysis. Indeed, other authors have suggested that a brief course of corticosteroids should be given to patients who have received etomidate [6].

Even if we take the results of this current study as evidence of equipoise in this issue, we have to ask ourselves 'What are the benefits of etomidate?' Use of this drug is 
certainly associated with hemodynamic stability [7], which is why it is lauded as an agent for emergent rapid sequence induction [8]. However, there are several other means to achieve this goal. One possibility is to improve the process of care during intubation. Jaber and colleagues (same research group who authored the paper under discussion) have previously demonstrated a dramatic reduction in life-threatening cardiopulmonary complications from $34 \%$ to $21 \%(P=0.03)$ after the introduction of a bundle of recommendations aimed at preventing intubation complications [9]. Of note, standardized induction agents, including etomidate, are an important component of this bundle, which also includes a fluid bolus, two operators, and the early use of vasopressors. Another possibility is to use alternate induction agents that have similar hemodynamic profiles to etomidate. In the KETASED trial, patients who required emergency intubation were randomized to etomidate or ketamine for induction [10]. There was no difference in terms of intubating conditions or immediate life-threatening complications between the two groups. Importantly there was also no difference in mortality between the two groups, although only $16 \%$ of the patients had sepsis. However, use of etomidate was associated with a much higher risk of adrenal insufficiency (86\% vs. $48 \%$, $P<0.0001)$ when compared with ketamine.

The central question regarding use of etomidate in patients who have severe sepsis and septic shock still remains 'Where do we go from here?' This study by Jung and colleagues adds to the debate and asks further important questions. In particular, 'Does early steroid supplementation modify the risk of etomidate in these patients?' However, in light of the conflicting data on clinical outcomes after use of etomidate and a readily available alternative agent that has a similar hemodynamic profile without the risk of adrenal suppression, namely ketamine, the use of etomidate in patients who have severe sepsis or septic shock continues to be controversial and potentially problematic.

\section{Acknowledgements}

The author would like to thank Dr William Henderson for critical revision of the manuscript.

\section{Competing Interests}

DEGG is supported through a Clinician Scientist Award from the Vancouver Coastal Health Research Institute.

\section{Author details}

'Department of Medicine, Division of Critical Care Medicine, Vancouver General Hospital, University of British Columbia, 855 West 12th Avenue, Vancouver, BC, Canada V5Z 1M9. ${ }^{2}$ Department of Anesthesia, Pharmacology and Therapeutics and Department of Medicine, Division of Critical Care Medicine, Vancouver General Hospital, University of British Columbia, 855 West 12th Avenue, Vancouver, BC, Canada V5Z 1M9. ${ }^{3}$ Centre for Clinical Epidemiology and Evaluation, Vancouver Coastal Health Research Institute, 828 West 10th Avenue, Vancouver, BC, Canada V5Z 1 M9.

Published: 27 December 2012

\section{References}

1. Jung B, Clavieras N, Nougaret S, Molinari N, Roquilly A, Cisse M, Carr J, Chanques $\mathrm{G}$, Asehnoune $\mathrm{K}$, Jaber $\mathrm{S}$ : Effects of etomidate on complications related to intubation and on mortality in septic shock patients treated with hydrocortisone: a propensity score analysis. Crit Care 2012, 16:R224.

2. Sprung CL, Annane D, Keh D, Moreno R, Singer M, Freivogel K, Weiss YG, Benbenishty J, Kalenka A, Forst H, Laterre P-F, Reinhart K, Cuthbertson BH, Payen D, Briegel J: Hydrocortisone therapy for patients with septic shock. NEng/ J Med 2008, 358:111-124.

3. Malerba G, Romano-Girard F, Cravoisy A, Dousset B, Nace L, Lévy B, Bollaert P-E: Risk factors of relative adrenocortical deficiency in intensive care patients needing mechanical ventilation. Intensive Care Med 2005, 31:388-392.

4. Vinclair M, Broux C, Faure P, Brun J, Genty C, Jacquot C, Chabre O, Payen J-F: Duration of adrenal inhibition following a single dose of etomidate in critically ill patients. Intensive Care Med 2008, 34:714-719.

5. Cuthbertson BH, Sprung CL, Annane D, Chevret S, Garfield M, Goodman S, Laterre PF, Vincent JL, Freivogel K, Reinhart K, Singer M, Payen D, Weiss YG: The effects of etomidate on adrenal responsiveness and mortality in patients with septic shock. Intensive Care Med 2009, 35:1868-1876.

6. Bloomfield R, Noble D: Etomidate and intensive care physicians. Intensive Care Med 2005, 31:1453; author reply 1454.

7. Harris CE, Murray AM, Anderson JM, Grounds RM, Morgan M: Effects of thiopentone, etomidate and propofol on the haemodynamic response to tracheal intubation. Anaesthesia 1988, 43:32-36.

8. Zed PJ, Abu-Laban RB, Harrison DW: Intubating conditions and hemodynamic effects of etomidate for rapid sequence intubation in the emergency department: an observational cohort study. Acad Emerg Med 2006, 13:378-383.

9. Jaber S, Jung B, Corne P, Sebbane M, Muller L, Chanques G, Verzilli D, Jonquet $\mathrm{O}$, Eledjam JJJ, Lefrant JYY: An intervention to decrease complications related to endotracheal intubation in the intensive care unit: a prospective, multiple-center study. Intensive Care Med 2010, 36:248-255.

10. Jabre P, Combes X, Lapostolle F, Dhaouadi M, Ricard-Hibon A, Vivien B, Bertrand L, Beltramini A, Gamand P, Albizzati S, Perdrizet D, Lebail G, CholletXemard C, Maxime V, Brun-Buisson C, Lefrant JY, Bollaert PE, Megarbane B, Ricard JD, Anguel N, Vicaut E, Adnet F: Etomidate versus ketamine for rapid sequence intubation in acutely ill patients: a multicentre randomised controlled trial. Lancet 2009, 374:293-300.

doi:10.1186/cc11889

Cite this article as: Griesdale DEG: Etomidate for intubation of patients who have sepsis or septic shock - where do we go from here? Critical Care 2012, 16:189. 